\title{
A Novel Function of Monomeric Amyloid $\beta$-Protein Serving as an Antioxidant Molecule against Metal-Induced Oxidative Damage
}

\author{
Kun Zou, Jian-Sheng Gong, Katsuhiko Yanagisawa, and Makoto Michikawa \\ Department of Dementia Research, National Institute for Longevity Sciences, Obu, Aichi 474-8522, Japan
}

Aggregated and oligomeric amyloid $\beta$-protein $(A \beta)$ is known to exhibit neurotoxicity. However, the action of $A \beta$ monomers on neurons is not fully understood. We have studied aggregation state-dependent actions of $A \beta$ and found an oligomer-specific effect of $A \beta$ on lipid metabolism in neurons (Michikawa et al., 2001). Here, we show a novel function of monomeric $A \beta 1-40$, which is the major species found in physiological fluid, as a natural antioxidant molecule that prevents neuronal death caused by transition metal-induced oxidative damage. Monomeric A $\beta 1-40$, which is demonstrated by SDS-PAGE after treatment with glutaraldehyde, protects neurons cultured in a medium containing 1.5 $\mu \mathrm{M} F$ (II) without antioxidant molecules. Metal ion chelators such as EDTA, CDTA (trans-1,2-diaminocyclohexane- $N, N, N^{\prime}, N^{\prime}$ tetraacetic acid), and DTPA (diethylenetriamine- $N, N, N^{\prime}, N^{\prime \prime}, N^{\prime \prime}-$ penta-acetic acid, an iron-binding protein, transferrin, and antioxidant scavengers such as catalase, glutathione, and vitamin $\mathrm{E}$ also inhibit neuronal death under the same conditions.
Monomeric A $\beta 1-40$ inhibits neuronal death caused by $\mathrm{Cu}(\mathrm{II})$, $\mathrm{Fe}(\mathrm{II})$, and $\mathrm{Fe}(\mathrm{III})$ but does not protect neurons against $\mathrm{H}_{2} \mathrm{O}_{2}$ induced damage. Monomeric $A \beta 1-40$ inhibits the reduction of $\mathrm{Fe}(\mathrm{III})$ induced by vitamin $\mathrm{C}$ and the generation of superoxides and prevents lipid peroxidation induced by $\mathrm{Fe}(\mathrm{II}) . \mathrm{A} \beta 1-42$ remaining as a monomer also exhibits antioxidant and neuroprotective effects. In contrast, oligomeric and aggregated A $\beta 1-40$ and $A \beta 1-42$ lose their neuroprotective activity. These results indicate that monomeric $A \beta$ protects neurons by quenching metal-inducible oxygen radical generation and thereby inhibiting neurotoxicity. Because aggregated $A \beta$ is known to be an oxygen radical generator, our results provide a novel concept that the aggregation-dependent biological effects of $A \beta$ are dualistic, being either an oxygen radical generator or its inhibitor.

Key words: Alzheimer's disease; amyloid $\beta$-protein; transition metals; oxygen radicals; antioxidant; neuronal death
One of the neuropathological hallmarks of Alzheimer's disease (AD) is the formation of extracellular amyloid deposits (Selkoe, 1994). The major component of the amyloid deposits is the 39-42 amino acid peptide of the amyloid $\beta$-protein $(\mathrm{A} \beta)$ (Glenner and Wong, 1984; Masters et al., 1985). One of the A $\beta$ species, ending with a $\mathrm{C}$ terminus at residue $40(\mathrm{~A} \beta 1-40)$, is the predominant soluble species in biological fluids (Vigo-Pelfrey et al., 1993; Ida et al., 1996). The longer form of $\mathrm{A} \beta$, ending at residue 42 $(\mathrm{A} \beta 1-42)$, accumulates initially and predominantly in parenchymal plaques (Roher et al., 1993; Iwatsubo et al., 1994). A $\beta 1-42$ is normally produced and secreted by cells in much lower quantities than $\mathrm{A} \beta 1-40$, which represents $\sim 90 \%$ of the total secreted $\mathrm{A} \beta$. It is believed that aggregated $\mathrm{A} \beta$ exerts neurotoxicity and initiates the progressive pathophysiology of AD (Mattson et al., 1993; Pike et al., 1993; Lorenzo and Yankner, 1994; Hartley et al., 1999). However, the function of monomeric $\mathrm{A} \beta$ on neurons is not yet fully understood.

It has been reported that the levels of metals such as zinc, iron, and copper are significantly concentrated in senile plaques (Smith et al., 1997; Lovell et al., 1998b). These observations followed original reports showing that these metals promote $\mathrm{A} \beta$ aggregation (Bush et al., 1994a,b; Huang et al., 1997; Atwood et al., 1998),

\footnotetext{
Received Dec. 3, 2001; revised March 19, 2002; accepted March 22, 2002.

This study was supported by a research grant for Longevity Sciences (H11-001), Research on Brain Science from the Ministry of Health and Welfare, and by Core Research for Evolutional Sciences and Technology, Japan.

Correspondence should be addressed to Dr. Makoto Michikawa, Department of Dementia Research, National Institute for Longevity Sciences, 36-3 Gengo, Morioka, Obu, Aichi, 474-8522, Japan. E-mail: michi@nils.go.jp.

Copyright (C) 2002 Society for Neuroscience $0270-6474 / 02 / 224833-09 \$ 15.00 / 0$
}

which is reversed by treatment with chelators in vitro (Huang et al., 1997) and in vivo (Cherny et al., 2001). In support of these findings, a recent study has clearly demonstrated that zinc and copper induce non- $\beta$-sheeted $\mathrm{A} \beta$ aggregation but inhibit $\beta$-sheeted aggregation and fibril formation (Yoshiike et al., 2001). Other studies have suggested that accumulated metals support the AD pathology as a possible source of reactive oxygen radicals (Smith et al., 1997; Lovell et al., 1998b; Sayre et al., 2000).

Recent studies showed that the surrounding regions of $\mathrm{A} \beta$ deposits in brains of patients with AD and Down's syndrome have no damage (Nunomura et al., 2000, 2001) and that there is an inverse correlation between $\mathrm{A} \beta$ burden and the levels of oxidized nucleic acids in the AD brain (Cuajungco et al., 2000b). Although aggregated $\mathrm{A} \beta$ is reported to generate free radicals (Hensley et al., 1994; Schubert and Chevion, 1995; Kay, 1997; Huang et al., 1999a; Monji et al., 2001b), these lines of evidence imply a new function of $\mathrm{A} \beta$ other than that of a radical generator. A previous report has suggested its antioxidant activity for lipoproteins (Kontush et al., 2001); however, no explanation has been provided as to the mechanism behind the disparate results from different laboratories regarding $\mathrm{A} \beta$-induced oxidative stress versus others suggesting antioxidant properties.

In light of the above, we have studied the aggregation statedependent actions of $\mathrm{A} \beta$ on neurons (Michikawa et al., 2001; Gong et al., 2002). Here, we show that monomeric A $\beta 1-40$ and also $\mathrm{A} \beta 1-42$ serve as antioxidant molecules protecting neurons from oxygen radicals generated in a metal-dependent manner, providing new insights into the strategy for developing a therapy for patients with AD. 


\section{MATERIALS AND METHODS}

Reagents and preparation. Synthetic human A $\beta 1-40$ was purchased from Peptide Institute Inc. (Osaka, Japan; lot numbers 510116 and 501001) and Bachem (Bubendorf, Switzerland; lot number 0538913). A $\beta 40-1$ (lot number D539530) was purchased from Bachem, and A $\beta 1-42$ (lot number 510523), A $\beta 1-16$ (lot number 490704), and A $\beta 25-35$ (lot number 500701) were purchased from Peptide Institute Inc. $\mathrm{A} \beta 1-40, \mathrm{~A} \beta 1-42$, and A $\beta 25-35$ were dissolved in DMSO at $2 \mathrm{mM}$ and then diluted with distilled water to a concentration of $200 \mu \mathrm{M}$. Although the solution was clear, it is known that an $\mathrm{A} \beta$ solution contains short fibrils (Naiki et al., 1998). To remove short fibrils, $\mathrm{A} \beta$ solutions were centrifuged at $100,000 \times g$ for 1 hr at $4^{\circ} \mathrm{C}$, using a Beckman Optima TLX table ultracentrifuge and a Beckman TLA-120.2 fixed-angle rotor. A $\beta 1-16$ was directly dissolved in water to a concentration of $200 \mu \mathrm{M}$. Oligomeric A $\beta 1-40$ was prepared as described previously (Michikawa et al., 2001). Transferrin, insulin, progesterone, putrescine, selenite, superoxide dismutase (SOD), catalase, glutathione, vitamin E, and vitamin E acetate were obtained from Sigma (St. Louis, MO). The B27 supplement and B27 minus antioxidants (B27-AO) were purchased from Invitrogen (Grand Island, NY). EDTA was purchased from Eastman Kodak Company (Rochester, NY). trans1,2-diaminocyclohexane- $N, N, N^{\prime}, N^{\prime}$-tetra-acetic acid (CDTA), diethylenetriamine- $N, N, N^{\prime}, N^{\prime \prime}, N^{\prime \prime}$-penta-acetic acid (DTPA), iron sulfate heptahydrate, iron nitrate nonahydrate, and copper sulfate pentahydrate were obtained from Wako Pure Chemical Industries, Ltd. (Osaka, Japan). Monoclonal antibody, namely, anti-4-hydroxy-2-nonenal (4-HNE) antibody, which recognizes oxidized 4-HNE, was purchased from NOF Corporation (Tokyo, Japan).

Cell culture. All experiments were performed in compliance with existing laws and the institutional guidelines. Cerebral cortical neuronal cultures were prepared from Sprague Dawley rats at embryonic day 17 as described previously (Michikawa and Yanagisawa, 1998). The dissociated single cells were suspended in a feeding medium and plated onto poly-D-lysine-coated 12 -well plates at a cell density of $5 \times 10^{-5}$. The feeding medium consisted of DMEM/F12 containing $0.1 \%$ bovine albumin fraction $\mathrm{V}$ solution (Invitrogen) and N2 (Bottenstein and Sato, 1979), B27, or B27-AO supplements.

Quantification of neuron survival. For assessment of cell viability of cultured neurons, phase-contrast photomicrographs were taken before treatment and at various time points after treatment. The number of viable neurons on each micrograph was determined in premarked microscope fields $(10 \times$ objective). Viable neurons were identified on the basis of morphological criteria. Neurons with intact neurites with uniform diameter and soma with a smooth round appearance were considered viable, whereas neurons with fragmented neurites and shrunken cell bodies were considered nonviable. In a pilot study, cell viability was confirmed by testing cell membrane permeability using propidium iodide (PI) or by staining with a viable cell-specific marker, calcein AM, as described previously (Michikawa and Yanagisawa, 1998). Neurons were stained with Hoechst 33342 (bis-benzamide; $2.5 \mu \mathrm{g} / \mathrm{ml}$ ), to visualize their nuclear morphology. Most neurons died during culturing in DMEM/F12 medium supplemented with B27-AO (B27-AO medium) or DMEM/F12 medium supplemented with $\mathrm{N} 2$ and $\mathrm{FeSO}_{4}, \mathrm{CuSO}_{4}$, or $\mathrm{Fe}\left(\mathrm{NO}_{3}\right)_{3}$. For each determination of cell viability, 1000-1400 cells were counted.

Thioflavin-T binding assay for aggregated $A \beta$. Determination of the aggregated state of $A \beta$ in solution was performed on the basis of a previously established method (LeVine, 1995; LeVine, 1999). The conditioned media, in which the cultures were incubated with $\mathrm{A} \beta$, were collected. Each well contained $50 \mu \mathrm{l}$ of each medium in $1 \mathrm{ml}$ per well of $5 \mu \mathrm{M}$ thioflavin-T in $50 \mathrm{~mm}$ glycin-NaOH, pH 8.5. Steady-state fluorescence intensities for each sample were determined in 48-well plates with a multiplate reader (Fluoroskan Ascent, Labsystems Inc., Franklin, MA) (excitation $446 \mathrm{~nm}$, emission $490 \mathrm{~nm}$ ). The culture media to which $\mathrm{A} \beta$ was not added were used as the background.

Cross-linking of $A \beta$ with glutaraldehyde. SDS-PAGE of cross-linked fA $\beta 1-40$ and iA $\beta 1-40$ was performed as described previously (Levine, 1995). Briefly, $8 \mu \mathrm{g}$ of each peptide in a stock solution $(200 \mu \mathrm{M})$ was diluted to $35 \mu \mathrm{l}$ with $\mathrm{H}_{2} \mathrm{O}$. One-tenth volume of glutaraldehyde $(3.5 \mu \mathrm{l}$ of $0.625 \%$ diluted from a $25 \%$ stock solution) was added to each solution followed by the addition of an excess amount of $\mathrm{NaBH}_{4}(10 \mu \mathrm{l}$ of $0.175 \mathrm{M}$, $6.6 \mathrm{mg} / \mathrm{ml}$, in $0.1 \mathrm{M} \mathrm{NaOH})$. After $10 \mathrm{~min}$ of incubation, $15 \mu \mathrm{l}$ of the SDS-PAGE sample buffer containing $100 \mathrm{~mm}$ dithiothreitol and $20 \%$ sucrose was added. Boiling of the amyloid peptides in the sample buffer was avoided, because SDS-resistant multimeric complexes are formed from non-cross-linked peptides during heating in SDS (LeVine, 1995).
Then, $20 \mu \mathrm{l}$ of the mixture was subjected to SDS-PAGE using a 4-20\% gradient gel as described previously (Michikawa et al., 2001). The gel was then visualized by silver staining. To compare the aggregation status of $\mathrm{A} \beta 1-40$ and $\mathrm{A} \beta 1-42$ in $8 \mathrm{mM}$ sodium phosphate, $\mathrm{pH} 7.4$, or DMEM/F12 medium, freshly dissolved $A \beta 1-40$ and $A \beta 1-42$ were incubated at $20 \mu \mathrm{M}$ for $3 \mathrm{hr}$ at $37^{\circ} \mathrm{C}$ in each solution. The protein concentration of each solution of $\mathrm{A} \beta 1-40$ and $\mathrm{A} \beta 1-42$ was determined, $2.8 \mu \mathrm{g}$ of each peptide was subjected to cross-linking, and the peptides were subjected to electrophoresis and silver staining.

Iron reduction assays. Assays were performed according to a previously reported method (Huang, 1999a). A $\beta 1-40(10 \mu \mathrm{M}), \mathrm{A} \beta 1-42(10 \mu \mathrm{M})$, DTPA $(10$ and $300 \mu \mathrm{M})$ or Fe(III) $(25 \mu \mathrm{M})$, and 3-(2-pyridyl)-5,6-bis(4sulfo-phenyl)-1,2,4-triazine (PDT) $(250 \mu \mathrm{M})$ were added to $1 \mathrm{ml}$ of $8 \mathrm{~mm}$ sodium phosphate, $\mathrm{pH} 7.4$, and rotated at $25^{\circ} \mathrm{C}$ for $6 \mathrm{hr}$. Vitamin $\mathrm{C}(10$ $\mu \mathrm{M})$ was then added, and the mixture was further incubated at $37^{\circ} \mathrm{C}$ for $14 \mathrm{hr}$. A solution containing $\mathrm{Fe}(\mathrm{III})$ and $\mathrm{A} \beta 1-40$ at the same concentrations in the absence of the indicator PDT was used to determine the background levels of this assay system. The absorbance at $562 \mathrm{~nm}$ indicates the amount of reduced iron ion, $\mathrm{Fe}(\mathrm{II})$.

Measurement of superoxide levels. The levels of intracellular superoxide anion radicals were measured using hydroethidium (HE), which is oxidized to a fluorescent ethidium cation by superoxides, using methods similar to those described previously (Bindokas et al., 1996). In brief, cells were incubated for $30 \mathrm{~min}$ in the presence of $5 \mu \mathrm{M} \mathrm{HE}$ (Molecular Probes, Eugene, OR) at $37^{\circ} \mathrm{C}$ in $5 \% \mathrm{CO}_{2}$ atmosphere, and confocal images of cell-associated $\mathrm{HE}$ fluorescence were acquired (excitation = $488 \mathrm{~nm}$ and emission $>560 \mathrm{~nm}$ ).

Western blot analysis for determination of lipid peroxidation. Cerebral cortices of Sprague Dawley rats at embryonic day 17 were isolated and minced with a cutter and incubated in PBS in the presence of 3 or $5 \mu \mathrm{M}$ $\mathrm{Fe}(\mathrm{II})$ with or without fA $\beta 1-40$ at $10 \mu \mathrm{M}$ for $4 \mathrm{hr}$ at $37^{\circ} \mathrm{C}$. The fragments were then homogenized in RIPA buffer ( $150 \mathrm{~mm} \mathrm{NaCl}, 10 \mathrm{~mm}$ Tris-HCl, $\mathrm{pH} 7.5,1 \%$ Nonidet P-40, $0.1 \%$ SDS, and $0.25 \%$ sodium deoxycholate) and centrifuged at $10,000 \times g$ for $10 \mathrm{~min}$ at $4^{\circ} \mathrm{C}$, and the supernatants were recovered. Protein concentrations of the supernatants were determined by the BCA method (Pierce, Rockford, IL). Western blot analysis was performed according to the methods described previously (Michikawa et al., 2001). In brief, $24 \mu \mathrm{g}$ of each protein was separated by 4-20\% gradient SDS-PAGE and electrotransferred onto nitrocellulose membranes. The membranes were incubated with monoclonal primary antibody, anti-4-HNE antibody, at $2 \mu \mathrm{g} / \mathrm{ml}$ overnight at $4^{\circ} \mathrm{C}$. The membranes were then washed in PBS containing 0.05\% Tween 20 (PBS-T) three times, followed by incubation with HRP-conjugated goat antimouse IgG (1:5000 dilution) for $1 \mathrm{hr}$ at room temperature. The membranes were washed four times in PBS-T and visualized with an ECL kit (Amersham Pharmacia Biotech, Buckinghamshire, UK).

\section{RESULTS}

\section{Freshly dissolved $\mathrm{A} \beta 1-40$ protects neurons against death induced by antioxidant-depleted medium}

We studied the effect of A $\beta 1-40$ on neuronal viability. The medium used was DMEM nutrient mixture (DMEM/F12, 50:50) containing B27-AO. When neurons were incubated in the B27-AO medium, cultured neurons appeared healthy $40 \mathrm{hr}$ after plating; however, neuronal death was induced $48 \mathrm{hr}$ after plating, and most of the cells were dead $64 \mathrm{hr}$ after plating (Fig. $1 a-c$ ). In contrast, neuronal death was inhibited in the presence of freshly dissolved $\mathrm{A} \beta 1-40$ (fA $\beta 1-40)$ at a concentration of $5 \mu \mathrm{M} 64 \mathrm{hr}$ after plating (Fig. $1 d$ ). Addition of DMSO at a final concentration of $1 \%$ DMSO to the B27-AO medium did not prevent or accelerate neuronal death (Fig. 1e). Figure 1e shows the timedependent curves of neuronal viability of the cultures treated with fA $\beta 1-40$ at various concentrations. The neuronal death induced by incubation in the B27-AO medium was inhibited by fA $\beta 1-40$ in a dose-dependent manner. Neuronal viability was maintained at the initial levels when the cultures were treated with fA $\beta 1-40$ at concentrations of 10 and $20 \mu \mathrm{M}$ until $4 \mathrm{~d}$ after the commencement of the treatment (Fig. 1e). The neurons at each time point were stained with Hoechst 33342 and PI. The viable neurons at culture day 2 had larger swollen cell bodies (Fig. 1b), and the 


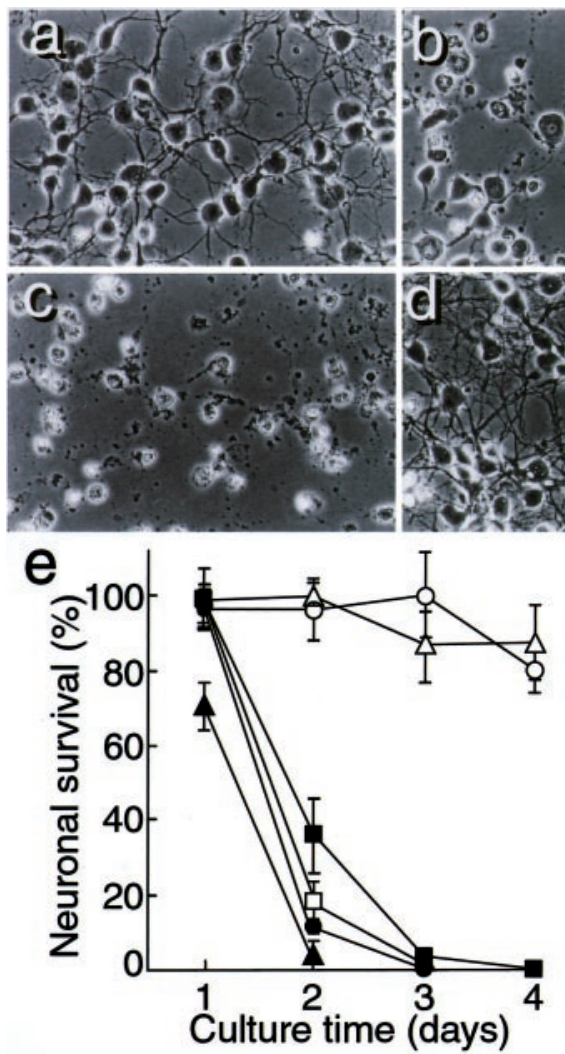

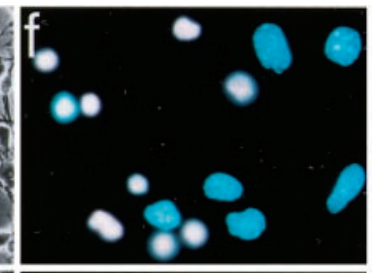
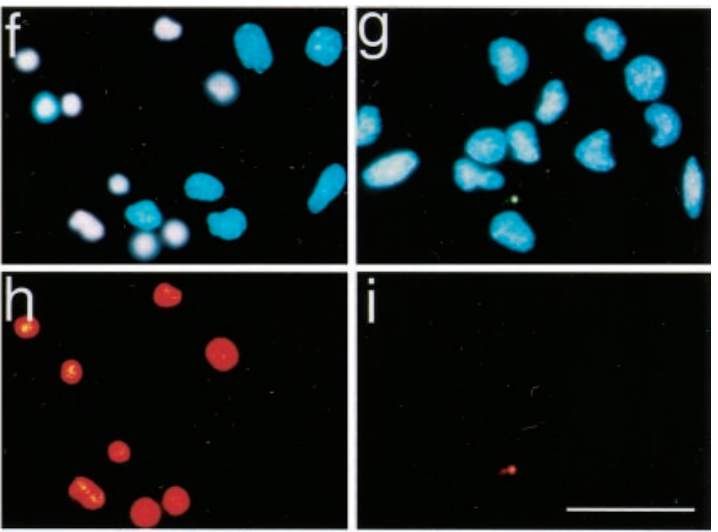

Control

Day 2

\begin{abstract}
Figure 1. fA $\beta 1-40$ inhibits neuronal death induced in an antioxidant-depleted medium. Rat cortical neurons were cultured in the B27-AO medium without $\mathrm{A} \beta 1-40$ treatment: $a$, $40 \mathrm{hr}$ culture; $b, 48 \mathrm{hr}$ culture; $c, 64 \mathrm{hr}$ culture; $d$, with fA $\beta 1-40(5 \mu \mathrm{M})$ treatment $4 \mathrm{hr}$ after plating, $64 \mathrm{hr}$ culture. $a-c$ are the same microscope field. $e$, Cell viability in the cultures treated with $\mathrm{A} \beta$ : none $(\bullet)$; DMSO vehicle $(\square)$; $\mathrm{A} \beta 1-40$ at $2 \mu \mathrm{M}(\mathbf{\square}), 10 \mu \mathrm{M}(\triangle)$, and 20 $\mu \mathrm{M}(\bigcirc)$; and $\mathrm{A} \beta 1-42$ at $10 \mu \mathrm{M}(\boldsymbol{\Delta})$. Data represent means \pm SE; $n=6$ each. Six independent experiments showed similar results. Representative Hoechst staining showing the nuclear morphology of cortical neurons with or without $\mathrm{A} \beta 1-40$ treatment is shown in $f, g$. Cell membrane permeability is indicated by PI staining in $h, i$.
\end{abstract}

nuclei of dead neurons were shrunken as demonstrated by Hoechst 22336 and PI staining (Figs. 1f,h). The effect of freshly prepared $\mathrm{A} \beta 1-42$ on neuronal viability was also examined. fA $\beta 1-42$ could not inhibit neurotoxicity but rather promoted neuronal death (Fig. 1e).

\section{Monomeric $A \beta 1-40$, but not oligomeric $A \beta 1-40$, has an ability to protect neurons in the $\mathrm{B} 27-\mathrm{AO}$ medium}

We examined the effect of incubated $A \beta 1-40$ (iA $\beta 1-40$ ), which was filtered and the protein concentration of which was determined before addition, on neuronal viability cultured in the B27-AO medium. As shown in Figure $2 a$, neuronal death occurred $72 \mathrm{hr}$ after the commencement of the treatment, which was completely inhibited by fA $\beta 1-40$, but not by iA $\beta 1-40$, at a concentration of $5 \mu \mathrm{M}$. Results of the quantitative analysis of neuronal viability within $72 \mathrm{hr}$ of incubation are shown in Figure $1 b$, showing that fA $\beta 1-40$ at concentrations of 5 and $10 \mu \mathrm{M}$ completely inhibited neuronal death, whereas iA $\beta 1-40$ inhibited neuronal death at $10 \mu \mathrm{M}$ but not at $5 \mu \mathrm{M}$. To determine the oligomeric state of $\mathrm{A} \beta$, the reaction of the conditioned medium of each culture with thioflavin-T was determined. As shown in Figure $2 c$, the value of the conditioned medium of the cultures treated with iA $\beta 1-40$ was significantly higher than that treated with fA $\beta 1-40$, indicating that $\mathrm{iA} \beta 1-40$ contains highly oligomerized $\mathrm{A} \beta$. To determine more directly that the amount of monomeric $\mathrm{A} \beta$ was decreased and that of oligomeric $\mathrm{A} \beta$ was increased, a crosslinking study of each $\mathrm{A} \beta$ sample was performed. As shown in Figure $2 d$, fA $\beta 1-40$ contains mostly monomers, whereas iA $\beta 1-40$ contains many oligomers, including dimers, trimers, and tetramers, in addition to decreased levels of monomers. These results indicate that $\mathrm{A} \beta$ monomers have a neuroprotective activity and that the lack of neuroprotective activity of $\mathrm{iA} \beta 1-40$ at $5 \mu \mathrm{M}$ is not caused by its toxic effect on neurons but rather by the low levels of monomers.

\section{Metal-binding protein and metal chelators inhibit neuronal death in the B27-AO medium}

Because neurotoxicity was induced in the media deficient of antioxidant reagents, it is reasonable to assume that the $\mathrm{A} \beta$ mediated neuronal protection may possibly be explained by an antioxidant action of $\mathrm{A} \beta$. Antioxidant actions include a direct antioxidant effect, and the indirect actions of fA $\beta 1-40$ include quenching of metal ions to inhibit secondary generation of free radicals. Thus, we examined the effect of molecules that have antioxidant activities. As shown in Figure $3 a$, catalase, glutathione, vitamin $\mathrm{E}$ acetate, and vitamin $\mathrm{E}$ inhibited neuronal death at culture day 2. Catalase and vitamin $\mathrm{E}$ acetate and vitamin $\mathrm{E}$ partially and completely inhibited cell death at culture day 4 , respectively; however, SOD did not show any neuroprotective activity. Because we have observed that the N2 supplements (Bottenstein and Sato, 1979) inhibited neuronal death induced by incubation in the B27-AO medium, we examined the inhibitory effect of each component of N2 supplements. Figure $3 b$ shows that among the components examined, only transferrin successfully inhibited neuronal death. Because transferrin is known to bind iron, inhibiting cell death by quenching the iron-dependent generation of reactive oxygen radicals (Halliwell and Gutteridge, 1989), it is reasonable to postulate that iron in DMEM/F12 plays a critical role in neuronal death in the B27-AO medium. Thus, we next examined the effect of various iron chelators on neuronal death under these conditions. EDTA $(400 \mu \mathrm{M})$, CDTA $(40 \mu \mathrm{M})$, and DTPA $(8 \mu \mathrm{M})$ protected neurons against toxicity induced in the B27-AO medium at culture day 4 (Table 1). 

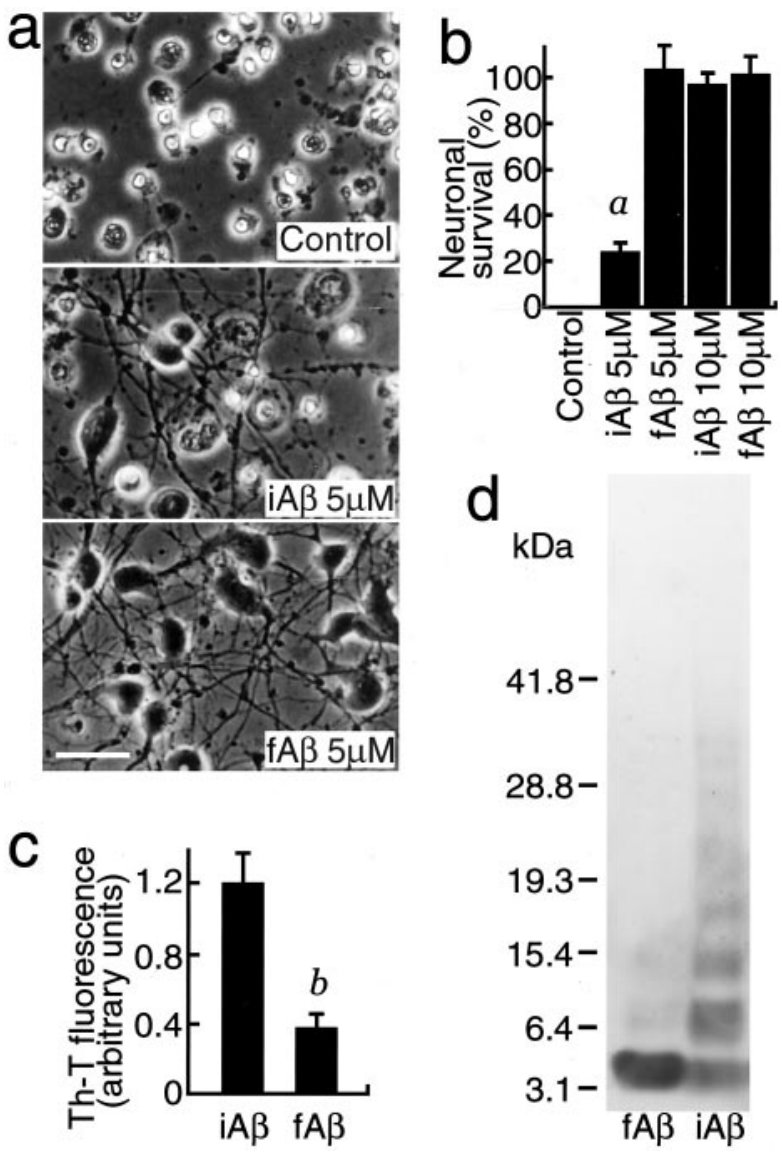

Figure 2. $\mathrm{fA} \beta 1-40$ but not iA $\beta 1-40$ protects neurons in the $\mathrm{B} 27-\mathrm{AO}$ medium. Neurons were treated with fA $\beta 1-40$ or iA $\beta 1-4024 \mathrm{hr}$ after plating. Phase-contrast photomicrographs were taken $(a)$, and the cell viability was determined $(b) 48 \mathrm{hr}$ after the commencement of each treatment. $a, p<0.0001$ versus fA $\beta 1-40(5 \mu \mathrm{M})$, iA $\beta 1-40(10 \mu \mathrm{M})$, and fA $\beta 1-40(10 \mu \mathrm{M}) . c$, Thioflavin-T fluorescence with the conditioned medium of each cultured neuron treated with fA $\beta 1-40$ or iA $\beta 1-40$ for 3 d. $b, p<0.01$ versus iA $\beta 1-40 . d$, Detection of oligomeric $\mathrm{A} \beta$ in $\mathrm{fA} \beta$ and iA $\beta$ samples by cross-linking with glutaraldehyde. fA $\beta 1-40$ or iA $\beta 1-40$ $(2.5 \mu \mathrm{g})$ was cross-linked with glutaraldehyde and subjected to a $4-20 \%$ SDS-PAGE. The gel was then visualized by silver staining.

\section{Monomeric $A \beta 1-40$ protects neurons against iron- and copper-mediated neuronal toxicity}

Because the culture medium, DMEM/F12 supplemented with B27-AO, contains $1.5 \mu \mathrm{M}$ Fe (II), $124 \mathrm{~nm}$ Fe(III), and $5.2 \mathrm{~nm}$ $\mathrm{Cu}(\mathrm{II})$, our findings that neuronal death induced in the B27-AO medium is prevented by antioxidant scavengers, metal chelators, and transferrin indicate that neurotoxicity is induced by oxygen radicals generated in an $\mathrm{Fe}(\mathrm{II})$-mediated manner. Thus, we next determined whether transition metal ions, such as iron and copper ions, and $\mathrm{H}_{2} \mathrm{O}_{2}$ exhibit neurotoxicity on cultured neurons, and whether fA $\beta 1-40$ has the ability to prevent this toxicity. Twentyfour hours after plating, neuronal cultures were treated with 1.5 $\mu \mathrm{M} \mathrm{CuSO}, 3.0 \mu \mathrm{M} \mathrm{FeSO}_{4}, 25 \mu \mathrm{M} \mathrm{Fe}\left(\mathrm{NO}_{3}\right)_{3}$, and $30 \mu \mathrm{M} \mathrm{H}_{2} \mathrm{O}_{2}$ in the presence or absence of $5 \mu \mathrm{M} \mathrm{fA} \beta 1-40$ in the $\mathrm{N} 2$ medium. After $24 \mathrm{hr}$ incubation, photographs were taken, and the neuronal viability was determined. As shown in Figure 4, $\mathrm{Cu}(\mathrm{II}), \mathrm{Fe}(\mathrm{II})$, $\mathrm{Fe}(\mathrm{III})$, and $\mathrm{H}_{2} \mathrm{O}_{2}$ caused cell death ( $a, c, e$, and $g$, respectively). fA $\beta 1-40$ at a concentration of $5 \mu \mathrm{M}$ inhibited cell death caused by these metals (Fig. $4 b, d, f$ ) but did not inhibit cell death caused by $\mathrm{H}_{2} \mathrm{O}_{2}$ (Fig. 4h), indicating that protection of neurons by fA $\beta 1-40$

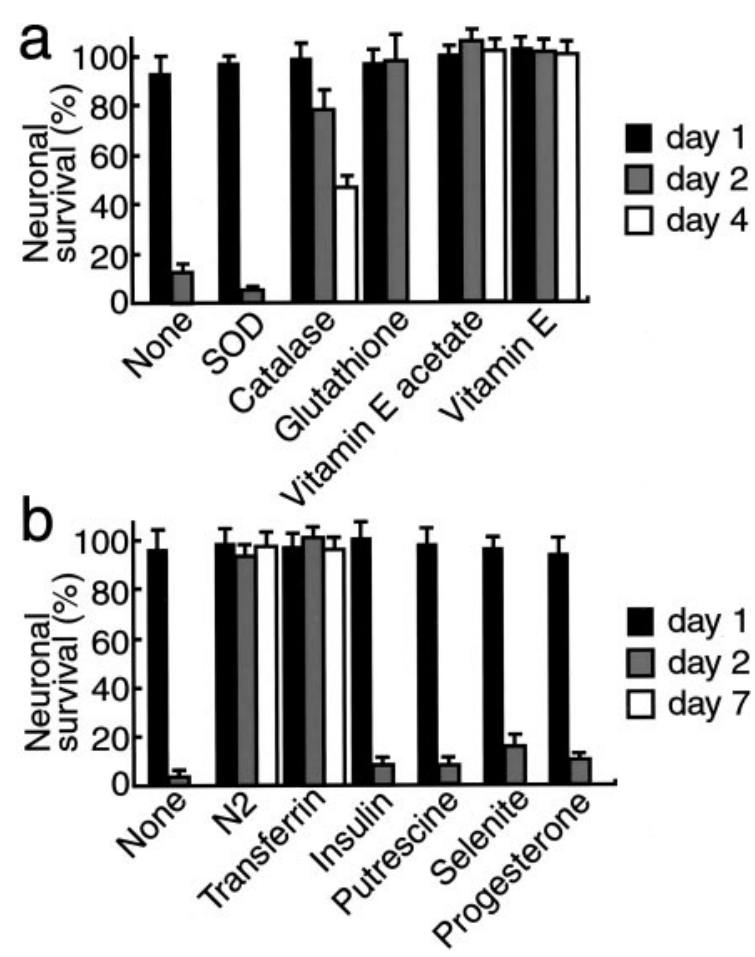

Figure 3. Transferrin and antioxidant scavengers inhibit neuronal death that occurred in the B27-AO medium. $a$, SOD $(1500 \mathrm{U} / \mathrm{ml})$, catalase $(21,600 \mathrm{U} / \mathrm{ml})$, glutathione $(450 \mu \mathrm{g} / \mathrm{ml})$, vitamin $\mathrm{E}$ acetate $(1 \mu \mathrm{g} / \mathrm{ml})$, or vitamin $\mathrm{E}(1 \mu \mathrm{g} / \mathrm{ml})$ was added to neuronal cultures maintained in the $\mathrm{B} 27-\mathrm{AO}$ medium $4 \mathrm{hr}$ after plating. $b, \mathrm{~N} 2$ supplements or each component of $\mathrm{N} 2$ supplements, transferrin $(100 \mu \mathrm{g} / \mathrm{ml})$, insulin $(5 \mu \mathrm{g} / \mathrm{ml})$, progesterone $(0.0063 \mu \mathrm{g} / \mathrm{ml})$, putrescine $(16.11 \mu \mathrm{g} / \mathrm{ml})$, and selenite $(0.0052 \mu \mathrm{g} / \mathrm{ml})$ was added to neuronal cultures maintained in the B27-AO medium $4 \mathrm{hr}$ after plating. Neuronal viability was determined as described in Materials and Methods at culture days 1, 2, and $4(a)$ or 1, 2, and $7(b)$.

$\begin{aligned} & \text { Table 1. Metal chelators inhibit neuronal death induced in the B27-AO } \\
& \text { medium }\end{aligned}$
\begin{tabular}{lcc} 
Chelators & Concentration $(\mu \mathrm{M})$ & Viability $(\%$ of control) \\
\hline None & 0 & 0 \\
EDTA & 400 & $60 \pm 3$ \\
CDTA & 40 & $99 \pm 4$ \\
DTPA & 8 & $93 \pm 7$
\end{tabular}

Primary cortical neurons were cultured in the B27-AO medium. Four hours after plating, the cultures were incubated with metal chelators. Cell viability was determined $48 \mathrm{~h}$ after the start of treatment. The data represent means \pm SE. $n=6$ each. Three independent experiments showed similar results.

is not caused by a direct antioxidant activity but by an indirect one via interaction with metal ions. The quantitative analysis of these experiments is shown in Figure $4 i$. We performed additional experiments to determine the effect of transferrin on neuronal toxicity induced by these metals. We found that $3.8 \mu \mathrm{M}$ transferrin inhibited $3.0 \mu \mathrm{M} \mathrm{Fe}(\mathrm{II})$ - and $25 \mu \mathrm{M} \mathrm{Fe}$ (III)-mediated neurotoxicity, but even $13 \mu \mathrm{M}$ transferrin did not inhibit $1.5 \mu \mathrm{M}$ $\mathrm{Cu}$ (II)-mediated neurotoxicity (data not shown), supporting the idea that $\mathrm{Fe}(\mathrm{II})$ but not $\mathrm{Cu}(\mathrm{II})$ is responsible for the generation of oxygen radicals and induces toxicity. This is supported by the fact that the B27-AO medium contains $1.5 \mu \mathrm{M}$ Fe(II), which is sufficiently high to induce cell toxicity, whereas it contains much lower concentrations of $\mathrm{Cu}(\mathrm{II})$ and $\mathrm{Fe}(\mathrm{III})$. 

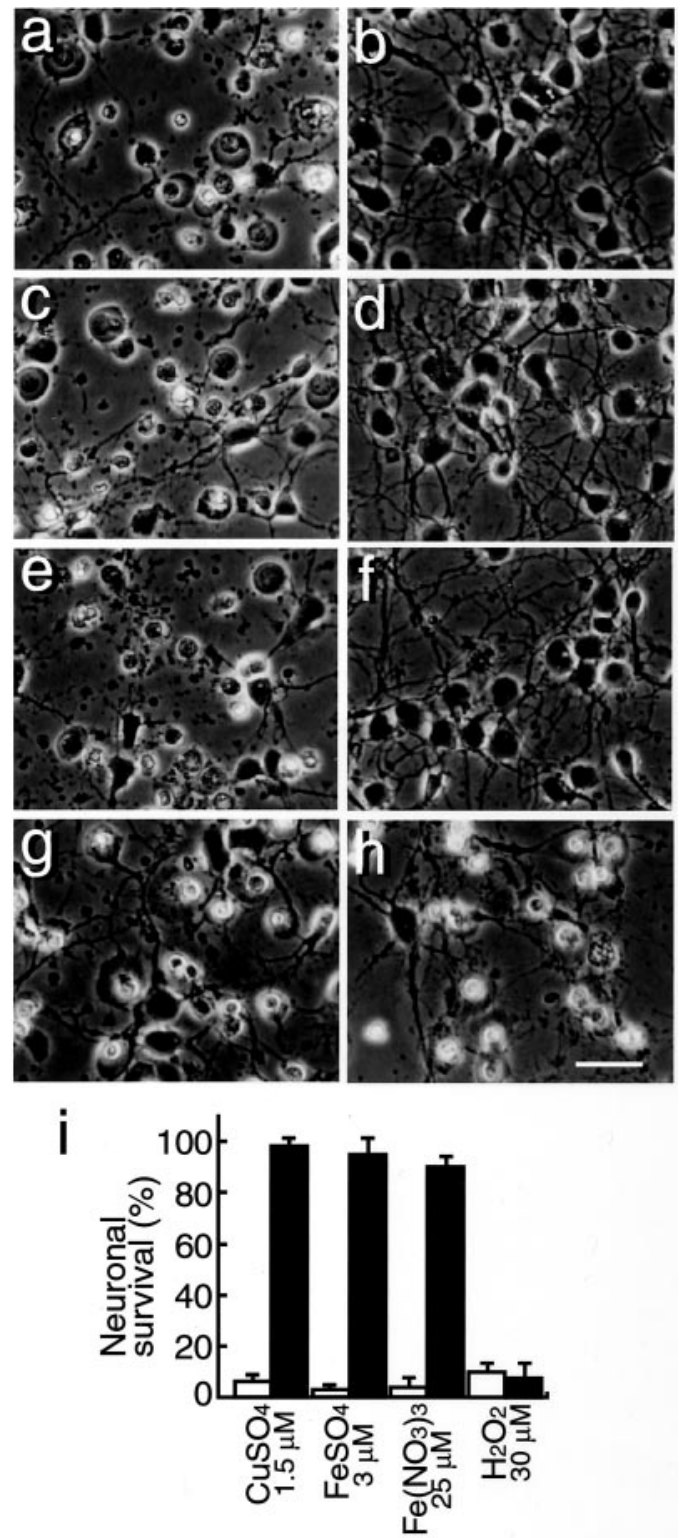

Figure 4. f A $\beta 1-40$ inhibits neuronal death induced by transition-metal ions. Neurons were cultured in N2 medium for $24 \mathrm{hr}$, followed by treatment with $1.5 \mu \mathrm{M} \mathrm{CuSO}_{4}(a, b), 3.0 \mu \mathrm{M} \mathrm{Fe} \mathrm{SO}(c, d), 25 \mu \mathrm{M} \mathrm{Fe}\left(\mathrm{NO}_{3}\right)_{3}$, $(e, f)$, and $30 \mu \mathrm{M} \mathrm{H}_{2} \mathrm{O}_{2}(g, h)$, and incubated for another $24 \mathrm{hr}$; photographs were taken to determine cell viability. $a, c, e$, and $g$ represent control cultures, and $b, d, f$, and $h$ represent neurons treated with fA $\beta 1-40$ $(5 \mu \mathrm{M})$ in addition to metal ions. $i$, Quantitative analysis of these treatments $24 \mathrm{hr}$ after the commencement of the metal treatment. Open and closed bars indicate cell viability in the cultures in the absence or presence, respectively, of fA $\beta 1-40(5 \mu \mathrm{M})$.

\section{Monomeric A $\boldsymbol{\beta} 1-40$ inhibits vitamin C-mediated reduction of $\mathrm{Fe}$ (III)}

Because reduced metal ions are known to generate oxygen radicals that initiate subsequent reactions of radical productions (Halliwell and Gutteridge, 1984), we determined whether fA $\beta 1-40$ has any effect on $\mathrm{Fe}(\mathrm{III})$ reduction. To examine the inhibitory effect of $\mathrm{fA} \beta 1-40$ on $\mathrm{Fe}(\mathrm{III})$ reduction, a vitamin $\mathrm{C}$-mediated metal reduction system was used. As shown in Figure $5 a$, fA $\beta 1-40$ inhibited $\mathrm{Fe}(\mathrm{III})$ reduction mediated by vitamin $\mathrm{C}$. In addition to $\mathrm{fA} \beta 1-40, \mathrm{fA} \beta 1-42, \mathrm{~A} \beta 1-16, \mathrm{~A} \beta 25-35$, and a metal ion chelator, DTPA, also inhibited Fe(III) reduction. Because the

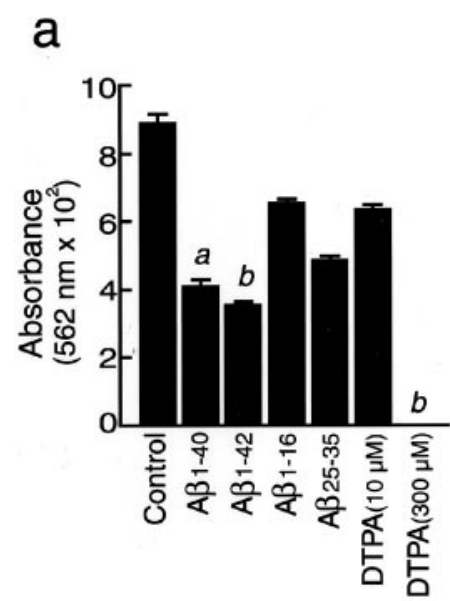

b

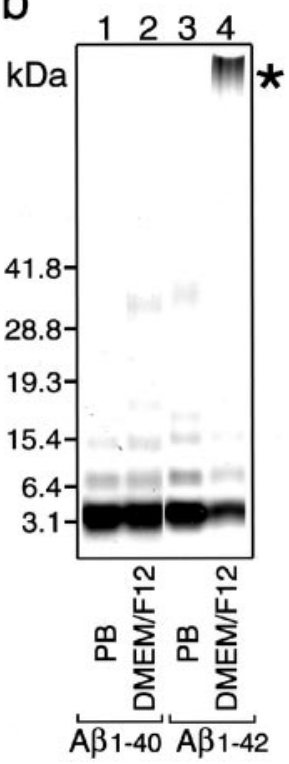

Figure 5. Inhibitory effect of $\mathrm{A} \beta$ peptides on vitamin $\mathrm{C}$-mediated $\mathrm{Fe}(\mathrm{III})$ reduction and the aggregation state of $\mathrm{A} \beta$ peptides in PB and DMEM/ F12. $a, \mathrm{~A} \beta$ peptides were incubated with Fe(III) $(25 \mu \mathrm{M})$ and PDT (250 $\mu \mathrm{M})$, followed by the addition of vitamin $\mathrm{C}(10 \mu \mathrm{M})$ and subsequent incubation for $14 \mathrm{hr}$ at $37^{\circ} \mathrm{C}$. The effects of freshly dissolved $\mathrm{A} \beta$ peptides $(10 \mu \mathrm{M})(\mathrm{fA} \beta 1-40, \mathrm{fA} \beta 1-42, \mathrm{fA} \beta 1-16$, and $\mathrm{fA} \beta 25-35$, all of which were dissolved in distilled water to make a stock solution at $200 \mu \mathrm{M}$ ) and DTPA $(10$ and $300 \mu \mathrm{M})$ on the reduction of $\mathrm{Fe}(\mathrm{III})$ were determined. The amount of reduced iron ions was determined by measuring the absorbance at $562 \mathrm{~nm}$. Data represent means \pm SE; $n=5$ replicate wells. $p<$ $0.001(a)$ and $p<0.0001(b)$ versus control. $b$, Freshly dissolved A $\beta 1-40$ and $\mathrm{A} \beta 1-42$ peptides at $20 \mu \mathrm{m}$ were incubated for $3 \mathrm{hr}$ at $37^{\circ} \mathrm{C}$ in $8 \mathrm{~mm}$ sodium phosphate buffer, pH 7.4 (lanes 1,3), or in DMEM/F12 medium (lanes 2,4). The aggregation state of $\mathrm{A} \beta 1-40$ (lanes 1,2) and $\mathrm{A} \beta 1-42$ (lane 3,4) was visualized by SDS-PAGE and silver staining after crosslinking as described in Materials and Methods. Note that A $\beta 1-42$ aggregated immediately in DMEM/F12 (*), but the majority of both peptides, $\mathrm{A} \beta 1-40$ in both solutions and $\mathrm{A} \beta 1-42$ in $\mathrm{PB}$, remained as a monomer.

action of $\mathrm{A} \beta$ is known to depend on the state of aggregation of the peptides, we next determined the aggregation states of $\mathrm{A} \beta$ used in this study by cross-linking of peptides with glutaraldehyde and subsequent silver staining. As shown in Figure $5 b$, most of both $\mathrm{A} \beta 1-40$ and $\mathrm{A} \beta 1-42$ incubated in $8 \mathrm{~mm}$ sodium phosphate buffer and $\mathrm{A} \beta 1-40$ incubated in DMEM/F12 for $3 \mathrm{hr}$ were found to be monomers, whereas fA $\beta 1-42$ incubated in DMEM/F12 for $3 \mathrm{hr}$ was found to form aggregation (Fig. $5 b, *$ ), and the amount of monomeric $\mathrm{A} \beta 1-42$ was significantly decreased (Fig. $5 b$ ).

\section{Generation of superoxides in the B27-AO medium and $\mathrm{Fe}(\mathrm{II})$-induced lipid peroxidation are inhibited by monomeric A $\beta 1-40$}

Using HE dye, we examined whether the generation of oxygen radicals is enhanced in the $\mathrm{B} 27-\mathrm{AO}$ medium and whether this enhancement is inhibited by fA $\beta 1-40$. As shown in Figure $6 a$, strong signals of oxidized ethidium dye were observed in some viable neurons with swollen cell bodies (Fig. 6a, arrows) and dead neurons with shrunken cell bodies (Fig. $6 c$ ), whereas the signals with ethidium dye in the cultures treated with fA $\beta 1-40(5 \mu \mathrm{M})$ were not detected (Fig. $6 b$ ). We then examined the effect of fA $\beta 1-40$ on $\mathrm{Fe}(\mathrm{II})$-induced lipid peroxidation in rat brain cortices by investigating the production of 4-HNE-modified proteins, a product of lipid peroxidation in rat brains, using a monoclonal antibody against 4-HNE-modified proteins. As shown in Figure 

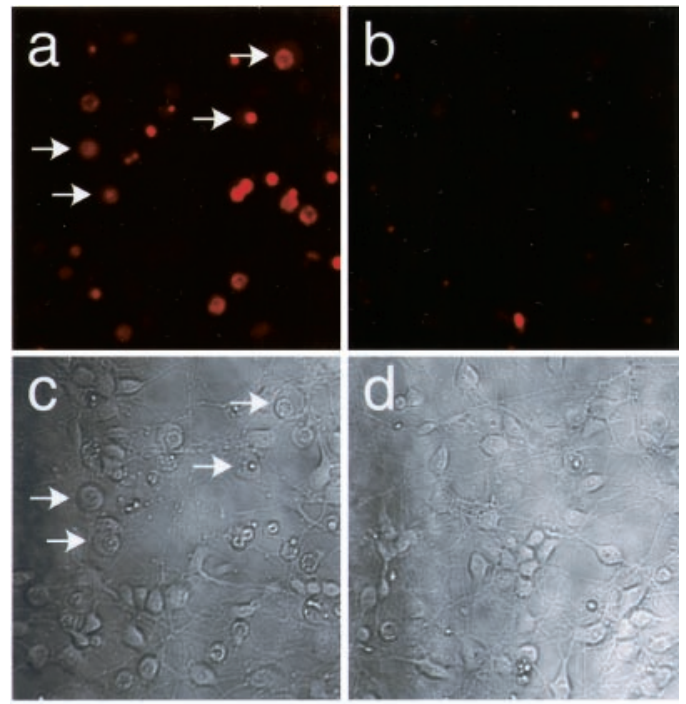

e

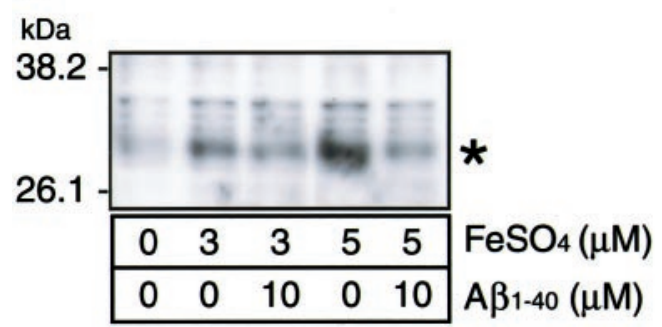

Figure 6. fA $\beta 1-40$ inhibits the generation of superoxide and lipid peroxidation. Neurons were treated with $(a, c)$ or without $(b, d) 5 \mu \mathrm{M}$ fA $\beta 1-404 \mathrm{hr}$ after plating and were cultured for $48 \mathrm{hr}$ in the B27-AO medium. The cultures were then incubated with $5 \mu \mathrm{M} \mathrm{HE}$ fluorescence $(a$, $b$ ) for $30 \mathrm{~min}$, and transmissive light micrographs of these cultures were taken. Note that the increased signal of superoxides was observed in swollen neurons (arrows) as well as in shrunken neurons in cultures without $\mathrm{fA} \beta(a) . e$, The effect of $\mathrm{A} \beta$ on the production of lipid peroxidation in rat cerebral cortices in the presence of Fe(II). Cerebral cortices were isolated, minced with a cutter, and incubated in PBS in the presence of 3 and $5 \mu \mathrm{M} \mathrm{Fe}(\mathrm{II})$ with or without fA $\beta 1-40$ at $10 \mu \mathrm{M}$ for $4 \mathrm{hr}$ at $37^{\circ} \mathrm{C}$. The fragments were then homogenized in RIPA buffer and centrif uged at $10,000 \times g$ for $10 \mathrm{~min}$ at $4^{\circ} \mathrm{C}$. The supernatant of the homogenate was subjected to Western blot analysis using anti-4-HNE antibody as the primary antibody.

$6 e(*)$, the amount of 4-HNE-modified proteins increased in brains incubated in PBS in the presence of 3 and $5 \mu \mathrm{M} \mathrm{Fe(II),}$ whereas treatment with $10 \mu \mathrm{M}$ fA $\beta 1-40$ attenuated this increase. This result indicates that $\mathrm{fA} \beta 1-40$ prevented lipid peroxidation of the brain tissues induced by oxygen radicals generated by the Fenton reaction.

\section{Comparison of effects of various kinds of $A \beta$ species on neuronal protection}

We examined the neuroprotective effect of $A \beta 1-42, A \beta 1-16$, and $\mathrm{A} \beta 25-35$, in addition to $\mathrm{A} \beta 1-40$, on cultured cells incubated in the B27-AO medium. Treatment of A $\beta 1-40$ at a concentration of $5 \mu \mathrm{M}$ inhibited neuronal death at a percentage of $95 \pm 5$, whereas $\mathrm{A} \beta 1-42$ at concentrations of $0.01,0.1,1,2,5,10$, and $20 \mu \mathrm{M}$, $\mathrm{A} \beta 1-16$ at concentrations of $1,2,5,10,20$, and 40 , or $\mathrm{A} \beta 25-35$ at concentrations of $1,2,5,10,20$, and 40 did not prevent neuronal death $48 \mathrm{hr}$ after the commencement of incubation (Table 2). In the case of $A \beta 1-42$, the thioflavin- $T$ value of the culture medium at the end of treatment significantly increased compared with that of the culture medium treated with $\mathrm{A} \beta 1-40, \mathrm{~A} \beta 1-16$, or $\mathrm{A} \beta 25-$ 35 , indicating that $\mathrm{A} \beta 1-42$ becomes highly aggregated in a culture medium. However, because $\mathrm{A} \beta 1-40$, when it remains as a monomer, has an antioxidant effect in the in vitro assay system (Fig. 5a), we next performed an experiment to determine whether monomeric $\mathrm{A} \beta 1-42$ at a concentration of $5 \mu \mathrm{M}$ has a neuroprotective effect on neurons. Because Congo red is known to inhibit oligomerization of $\mathrm{A} \beta$ by stabilizing $\mathrm{A} \beta$ monomer (Podlisny et al., 1995, 1998), we used Congo red to maintain $\mathrm{A} \beta 1-42$ as a monomer. As shown in Table 2, concurrent treatment of $100 \mu \mathrm{M}$ Congo red with $5 \mu \mathrm{M} \mathrm{A} \beta 1-42$ inhibited neuronal death, whereas treatment with $100 \mu \mathrm{M}$ Congo red alone did not. The thioflavin-T value of these conditioned media was not determined, because Congo red affects the thioflavin-T assay system. These data indicate that monomeric $\mathrm{A} \beta$, regardless of its species, $\mathrm{A} \beta 1-40$ or A $\beta 1-42$, rescues neurons.

\section{Effect of tachykinin neuropeptides on monomeric A $\beta$ 1-40-mediated neuroprotection}

Because a previous study has demonstrated the neurotrophic effects of $A \beta 1-40$, which can be reversed by tachykinin neuropeptides (Yankner et al., 1990), we further examined whether the neuroprotective effect of monomeric $\mathrm{A} \beta 1-40$ is inhibited by tachykinin neuropeptides. In our culture system, takykinine neuropeptides such as substance $\mathrm{P}$, physalaemin, eledoisin, neurokinin $\mathrm{A}$, and neurokinin $\mathrm{B}$ at $1,2,5,10$, and $20 \mu \mathrm{M}$ did not inhibit neuronal death. Moreover, substance $\mathrm{P}$ and physalaemin did not inhibit the neuroprotective effect of A $\beta 1-40$ (Table 3). These results indicate that the mechanism underlying the neurotrophic effects of $A \beta 1-40$ is different from that underlying the antioxidant functions of monomeric $\mathrm{A} \beta$.

\section{DISCUSSION}

In this study, we demonstrated a novel function of monomeric A $\beta 1-40$ as an antioxidant molecule on cultured neurons. Monomeric A $\beta 1-40$ exhibits a neuroprotective effect on neurons by quenching transition metal-mediated oxygen radical generation; however, oligomeric A $\beta 1-40$ loses its neuroprotective activity. Monomeric A $\beta 1-42$ also exhibits a neuroprotective effect; however, when monomeric $A \beta 1-42$ is incubated in the culture medium, it rapidly aggregates and exhibits neurotoxicity, whereas monomeric A $\beta 1-40$ remains as a monomer under the same conditions and protects neurons. These findings indicate a novel concept that the biological action of $\mathrm{A} \beta$ is dualistic. $\mathrm{A} \beta$, as a monomer, functions as an antioxidant molecule, preventing the generation of oxygen radicals, whereas oligomerized or aggregated $\mathrm{A} \beta$ not only loses its antioxidant activity but also contributes to the generation of oxygen radicals (Kay, 1997; Monji et al., 2001a,b), disrupts lipid homeostasis (Michikawa et al., 2001; Gong et al., 2002), and eventually exhibits neurotoxicity (Mattson et al., 1993; Pike et al., 1993; Lorenzo and Yankner, 1994).

Neuronal death induced in the B27-AO medium is inhibited by the addition of radical scavengers, indicating that neuronal toxicity is caused by oxygen radicals. The B27-AO medium contains $1.5 \mu \mathrm{M} F($ II), $124 \mathrm{~nm} \mathrm{Fe}(\mathrm{III})$, and $5.2 \mathrm{~nm} \mathrm{Cu}(\mathrm{II})$, and redox-active transition metals such as iron and copper are known to stimulate oxygen radical chain reactions (Halliwell and Gutteridge, 1984). Because $1.5 \mu \mathrm{M}$ or higher concentrations of $\mathrm{Fe}(\mathrm{II})$ and $\mathrm{Cu}(\mathrm{II})$ induce neuronal death in culture [our unpublished data and previous reports (White et al., 1999; Wang and Cynader, 2001)], $\mathrm{Fe}(\mathrm{II})$ is most likely responsible for inducing neurotoxicity by generating oxygen radicals in the B27-AO medium. Furthermore, 


\begin{tabular}{|c|c|c|c|}
\hline Peptides & Concentration $\mathrm{A} \beta(\mu \mathrm{M})$ & Viability (\% of control) & Thioflavin- $\mathrm{T}$ arbitrary unit $(\mathrm{A} \beta, 5 \mu \mathrm{M})$ \\
\hline None & 0 & 0 & 0 \\
\hline $\mathrm{A} \beta 1-40$ & 5 & $95 \pm 5$ & $0.11 \pm 0.12$ \\
\hline $\mathrm{A} \beta 1-42$ & $0.01,0.1,1,2,5,10,20$ & 0 & $0.51 \pm 0.12^{*}$ \\
\hline $\mathrm{A} \beta 1-16$ & $1,2,5,10,20,40$ & 0 & $0.02 \pm 0.01$ \\
\hline$A \beta 25-35$ & $1,2,5,10,20,40$ & 0 & $0.02 \pm 0.04$ \\
\hline $\mathrm{A} \beta 40-1$ & $1,2,5,10,20,40$ & 0 & ND \\
\hline $\mathrm{A} \beta 1-42+\mathrm{CR}(100 \mu \mathrm{M})$ & 5 & $96 \pm 4$ & ND \\
\hline CR $(100 \mu \mathrm{M})$ & 0 & 0 & ND \\
\hline
\end{tabular}

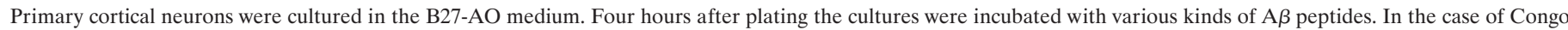

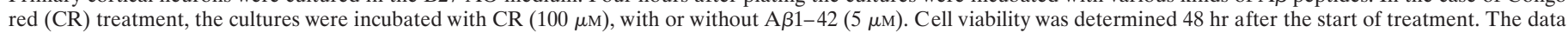
represent means \pm SE. $n=6$ each. Three independent experiments showed similar results. ${ }^{*} p<0.0001$ versus A $\beta 1-40$, A $\beta 1-16$, and A $\beta 25-35$. ND, Not determined.

Table 3. Effect of substance $P$ and physalaemin on the neuroprotective effect of monomeric Aß1-40 in the B27-AO medium

\begin{tabular}{lc} 
Treatment & $\begin{array}{c}\text { Viability } \\
(\% \text { of control })\end{array}$ \\
\hline None & 0 \\
A $\beta 1-40(10 \mu \mathrm{M})$ & $95 \pm 5$ \\
A $\beta 1-40(10 \mu \mathrm{M})+$ substance P $(20 \mu \mathrm{M})$ & $101 \pm 12$ \\
A $\beta 1-40(10 \mu \mathrm{M})+$ physalaemin $(20 \mu \mathrm{M})$ & $94 \pm 6$ \\
Substance P $(1,2,5,10,20 \mu \mathrm{M})$ & 0 \\
Physalaemin $(1,2,5,10,20 \mu \mathrm{M})$ & 0 \\
Eledoisin $(1,2,5,10,20 \mu \mathrm{M})$ & 0 \\
Neurokinin A $(1,2,5,10,20 \mu \mathrm{M})$ & 0 \\
Neurokinin B $(1,2,5,10,20 \mu \mathrm{M})$ & 0
\end{tabular}

$\overline{\text { Primary cortical neurons were cultured in the B27-AO medium. Four hours after }}$ plating the cultures were incubated with $10 \mu \mathrm{M}$ freshly dissolved $\mathrm{A} \beta 1-40$ in the presence or absence of substance $\mathrm{P}(20 \mu \mathrm{M})$ or physalaemin $(20 \mu \mathrm{M})$. The cultures were also treated with substance $\mathrm{P}$, physalaemin, eledoisin, neurokinin $\mathrm{A}$, and neurokinin B at various concentrations. Cell viability was determined $48 \mathrm{hr}$ after the start of treatment. The data represent means \pm SE. $n=6$ each.

the facts that transferrin successively protects neurons in the B27-AO medium (Fig. 3b) and inhibits Fe(II)-mediated neuronal death in $\mathrm{N} 2$ medium, whereas it does not prevent $\mathrm{Cu}$ (II)-induced neuronal death (data not shown), strongly support this notion. Thus, it is possible that fA $\beta 1-40$ protects neurons from oxygen radicals generated in an $\mathrm{Fe}(\mathrm{II})$-mediated manner.

Antioxidant actions include a direct antioxidant action such as that of scavengers and indirect actions including the quenching metal ions to inhibit secondary generation of free radicals. The neuroprotective activity of monomeric A $\beta 1-40$ includes an inhibitory effect on the generation of superoxides in cultured neurons and lipid peroxidation in brains (Fig. 6). Furthermore, the direct inhibitory effects of monomeric $\mathrm{A} \beta 1-40$ on metal reduction induced by vitamin $\mathrm{C}$ are also demonstrated (Fig. 5). These findings, together with the result showing that monomeric A $\beta 1-40$ does not serve as a radical scavenger (Fig. 4), indicate that the neuroprotective activity of $\mathrm{A} \beta 1-40$ is not caused by a direct antioxidant effect but rather by an indirect effect of this peptide, probably the sequestration of metal ions leading to the quenching of the secondary generation of oxygen radicals as other metal-binding proteins do (Halliwell and Gutteridge, 1989).

Free-radical involvement in AD pathogenesis is a well established hypothesis (Lovell et al., 1998a; Markesbery and Lovell, 1998). A $\beta$ is widely believed to serve as a neurotoxic molecule by producing oxygen radicals leading to cell dysfunction and death (Behl et al., 1994; Hensley et al., 1994). The oxygen radicals generated by the interaction of $\mathrm{A} \beta$ with redox-active metal ions are suggested to be the possible source of $\mathrm{A} \beta$ neurotoxicity, which is suppressed by the redox-inactive form of zinc or metal ion chelators (Huang et al., 1999a,b; Cuajungco et al., 2000a). These lines of evidence seem to contradict our present results that monomeric A $\beta 1-40$ is a potent antioxidant molecule. This discrepancy can be explained by the notion that the action of $A \beta$ is aggregation state-dependent. We show that monomeric $\mathrm{A} \beta 1-40$ protects neurons from metal-induced neurotoxicity, whereas iA $\beta 1-40$ contains fewer $\mathrm{A} \beta$ monomers but more oligomers (Fig. $2 d$ ), which could be the reason for the loss of its neuroprotective ability. This is also the case for A $\beta 1-42$, because we have found that $\mathrm{A} \beta 1-42$, remaining as a monomer in $\mathrm{PB}$, inhibits the reduction of $\mathrm{Fe}$ (III) caused by vitamin $\mathrm{C}$ as does $\mathrm{A} \beta 1-40$ (Fig. $5 a$ ), indicating that monomeric $\mathrm{A} \beta 1-42$ also functions as an antioxidant molecule. In addition, the finding that $\mathrm{A} \beta 1-42$, when it is maintained as a monomer by coincubation with Congo red in DMEM/F12 medium, exhibits neuroprotective activity (Table 2) strongly supports this notion. However, when fA $\beta 1-42$ is incubated in DMEM/F12 medium that contains salt, it aggregates rapidly (Fig. 5b, Table 2) and exhibits neurotoxicity (Fig. 1e, Table 2), whereas fA $\beta 1-40$ remaining as a monomer under the same conditions protects neurons (Figs. 1e, 5b). Thus, under physiological conditions, A $\beta 1-42$, a highly amyloidogenic peptide, rapidly aggregates, loses its neuroprotective activity, generates free radicals, and subsequently exhibits neurotoxicity (Pike et al., 1993; Lorenzo and Yankner, 1994; Roher et al., 1996; Kay, 1997; Huang et al., 1999b; Cuajungco et al., 2000b; Monji et al., $2001 a, b)$. These lines of evidence suggest that it may not the differences in $\mathrm{A} \beta$ species, $\mathrm{A} \beta 1-40$ or $\mathrm{A} \beta 1-42$, but those in the state of aggregation, monomers, or other states of aggregation such as oligomers or fibrils, that determine whether the action of $\mathrm{A} \beta$ is either neuroprotective or neurotoxic.

Another possible explanation for the discrepancy between the effect of $A \beta 1-40$ and that of $A \beta 1-42$ on neuronal survival may be that at low iron $/ \mathrm{A} \beta$ binding ratios, iron is captured by $\mathrm{A} \beta$ and sequestered from inducing oxygen radical generation, but at higher iron/A $\beta$ ratios, the interaction of $\mathrm{A} \beta$ and iron promotes oxygen radical generation (Huang et al., 1999a). Because A $\beta 1-42$ is suggested to bind iron with greater affinity than $A \beta 1-40$ (Atwood et al., 2000), it may be possible to postulate that $\mathrm{A} \beta 1-42$ may acquire gain of adverse action at lower concentrations than A $\beta 1-40$.

One may say that because a previous study has demonstrated that aggregated $A \beta$ does not lose the stoichiometry of copper binding (Atwood et al., 2000), an increased amount of oligomer- 
ized $\mathrm{A} \beta$ may undergo oxidization, reduce metal ions, and serve as an oxygen radical generator (Huang et al., 1999a), leading to neuronal death. Actually, at present we have no evidence indicating that oligomeric $\mathrm{A} \beta$ has lesser binding affinity to iron than monomeric $\mathrm{A} \beta$. This may be the case for $\mathrm{A} \beta 1-42$, because A $\beta 1-42$ that rapidly aggregates in the culture medium not only loses its neuroprotective activity but also exhibits neurotoxicity (Fig. 1e); however, this may not be the case for $\mathrm{A} \beta 1-40$. Our findings that $5 \mu \mathrm{M}$ iA $\beta 1-40$ loses its neuroprotective effect on neurons, whereas $10 \mu \mathrm{M}$ iA $\beta 1-40$ protects neurons (Fig. $2 b$ ), do not favor the idea that the loss of neuroprotective function is caused by oxidized oligomeric $\mathrm{A} \beta$ but favor the notion that monomeric but not oligomeric $\mathrm{A} \beta 1-40$ can serve as an antioxidant molecule.

The last question to be addressed is that the neuroprotective effects of monomeric A $\beta 1-40$ shown in our present study are the same as the previously reported neurotrophic effects of $A \beta 1-40$, which can be reversed by tachykinin neuropeptides (Yankner et al., 1990). However, monomeric A $\beta 1-40$ has a neuroprotective effect even on mature neurons at high concentrations, whereas takykinin neuropeptides including substance $\mathrm{P}$ and physalaemin at 10 and $20 \mu \mathrm{M}$ did not inhibit neuronal death in our culture system. Moreover, substance $\mathrm{P}$ and physalaemin did not reverse the neuroprotective effect of $\mathrm{A} \beta 1-40$ (Table 3), indicating that the mechanism underlying the neurotrophic effects of $A \beta 1-40$ is different from that underlying the antioxidant functions of monomeric $\mathrm{A} \beta$.

The notion that monomeric $\mathrm{A} \beta 1-40$ functions as an antioxidant is supported by previous studies showing that the surrounding regions of $\mathrm{A} \beta$ deposits in the brains of patients with $\mathrm{AD}$ and Down's syndrome have no damage (Nunomura et al., 2000, 2001) and that the inverse correlation is found between $\mathrm{A} \beta$ burden and levels of oxidized nucleic acids in AD brain (Cuajungco et al., $2000 \mathrm{~b}$ ). Interestingly, a recent report suggests that brain oxidative damage occurs before $A \beta$ accumulation in the brains of a model mouse of AD amyloidosis (Pratico et al., 2001). Previous reports have shown that $\mathrm{A} \beta 1-42$ accumulates with aging, whereas A $\beta 1-40$ does not but accumulates in AD brains (Funato et al., 1998), and that oxidative stress promotes amyloidogenesis (Misonou et al., 2000). These lines of evidence may allow us to assume that oxygen radicals generated in an age-dependent manner enhance generation of $\mathrm{A} \beta$, which may protect neurons from oxygen radical toxicity generated by metal-dependent chain reactions. However, with the increasing amount of $\mathrm{A} \beta$ serving as an antioxidant, $\mathrm{A} \beta$ aggregates with longer incubation periods in extracellular local fluid and, in turn, exhibits neurotoxicity.

On the basis of our findings, we envisage that $\mathrm{A} \beta$ may serve dual actions both by being involved in mechanisms attempting to quench oxidative stress and neurotoxicity probably by sequestrating metal ions when $A \beta$ is in a monomeric state and by exhibiting neurotoxicity when $A \beta$ is highly oligomerized and aggregated by generating oxygen radicals in a metal-mediated manner. Hence, although the toxic actions of $\mathrm{A} \beta$ have been exaggerated to date, our observations may provide a new insight into the strategies for development of $\mathrm{AD}$ therapy that not only reduction of the amount of $\mathrm{A} \beta$ but also inhibition of $\mathrm{A} \beta$ aggregation could be the pivotal target for AD therapy.

\section{REFERENCES}

Atwood CS, Moir RD, Huang X, Scarpa RC, Bacarra NM, Romano DM, Hartshorn MA, Tanzi RE, Bush AI (1998) Dramatic aggregation of Alzheimer $\mathrm{A} \beta$ by $\mathrm{Cu}(\mathrm{II})$ is induced by conditions representing physiological acidosis. J Biol Chem 273:12817-12826.
Atwood CS, Scarpa RC, Huang X, Moir RD, Jones WD, Fairlie DP, Tanzi RE, Bush AI (2000) Characterization of copper interactions with alzheimer amyloid $\beta$ peptides: identification of an attomolaraffinity copper binding site on amyloid $\beta 1-42$. J Neurochem 75:1219-1233.

Behl C, Davis JB, Lesley R, Schubert D (1994) Hydrogen peroxide mediates amyloid $\beta$-protein toxicity. Cell 77:817-827.

Bindokas VP, Jordan J, Lee CC, Miller RJ (1996) Superoxide production in rat hippocampal neurons: selective imaging with hydroethidine. J Neurosci 16:1324-1336.

Bottenstein JE, Sato GH (1979) Growth of a rat neuroblastoma cell line in serum-free supplemented medium. Proc Natl Acad Sci USA 76:514-517.

Bush AI, Pettingell Jr WH, Paradis MD, Tanzi RE (1994a) Modulation of $\mathrm{A} \beta$ adhesiveness and secretase site cleavage by zinc. J Biol Chem 269:12152-12158.

Bush AI, Pettingell WH, Multhaup G, Paradis MD, Vonsattel JP, Gusella JF, Beyreuther K, Masters CL, Tanzi RE (1994b) Rapid induction of Alzheimer A $\beta$ amyloid formation by zinc. Science 265:1464-1467.

Cherny RA, Atwood CS, Xilinas ME, Gray DN, Jones WD, McLean CA, Barnham KJ, Volitakis I, Fraser FW, Kim Y, Huang X, Goldstein LE, Moir RD, Lim JT, Beyreuther K, Zheng H, Tanzi RE, Masters CL, Bush AI (2001) Treatment with a copper-zinc chelator markedly and rapidly inhibits $\beta$-amyloid accumulation in Alzheimer's disease transgenic mice. Neuron 30:665-676.

Cuajungco MP, Faget KY, Huang X, Tanzi RE, Bush AI (2000a) Metal chelation as a potential therapy for Alzheimer's disease. Ann NY Acad Sci 920:292-304.

Cuajungco MP, Goldstein LE, Nunomura A, Smith MA, Lim JT, Atwood CS, Huang X, Farrag YW, Perry G, Bush AI (2000b) Evidence that the $\beta$-amyloid plaques of Alzheimer's disease represent the redoxsilencing and entombment of $\mathrm{A} \beta$ by zinc. J Biol Chem 275: 19439-19442.

Funato H, Yoshimura M, Kusui K, Tamaoka A, Ishikawa K, Ohkoshi N, Namekata K, Okeda R, Ihara Y (1998) Quantitation of amyloid $\beta$-protein $(\mathrm{A} \beta)$ in the cortex during aging and in Alzheimer's disease. Am J Pathol 152:1633-1640.

Glenner GG, Wong CW (1984) Alzheimer's disease: initial report of the purification and characterization of a novel cerebrovascular amyloid protein. Biochem Biophys Res Commun 120:885-890.

Gong JS, Sawamura N, Zou K, Sakai J, Yanagisawa K, Michikawa M (2002) Amyloid $\beta$-protein affects cholesterol metabolism in cultured neurons: implications for pivotal role of cholesterol in the amyloid cascade. J Neurosci Res, in press.

Halliwell B, Gutteridge JM (1984) Oxygen toxicity, oxygen radicals, transition metals and disease. Biochem J 219:1-14.

Halliwell B, Gutteridge JMC (1989) Protection by sequestration of metal ions. In: Free radicals in biology and medicine, Ed 2, pp 131-133. New York: Oxford UP.

Hartley DM, Walsh DM, Ye CP, Diehl T, Vasquez S, Vassilev PM, Teplow DB, Selkoe DJ (1999) Protofibrillar intermediates of amyloid $\beta$-protein induce acute electrophysiological changes and progressive neurotoxicity in cortical neurons. J Neurosci 19:8876-8884.

Hensley K, Carney JM, Mattson MP, Aksenova M, Harris M, Wu JF, Floyd RA, Butterfield DA (1994) À model for $\beta$-amyloid aggregation and neurotoxicity based on free radical generation by the peptide: relevance to Alzheimer disease. Proc Natl Acad Sci USA 91: 3270-3274.

Huang X, Atwood CS, Moir RD, Hartshorn MA, Vonsattel JP, Tanzi RE, Bush AI (1997) Zinc-induced Alzheimer's A $\beta 1-40$ aggregation is mediated by conformational factors. J Biol Chem 272:26464-26470.

Huang X, Atwood CS, Hartshorn MA, Multhaup G, Goldstein LE, Scarpa RC, Cuajungco MP, Gray DN, Lim J, Moir RD, Tanzi RE, Bush AI (1999a) The A $\beta$ peptide of Alzheimer's disease directly produces hydrogen peroxide through metal ion reduction. Biochemistry 38:7609-7616.

Huang X, Cuajungco MP, Atwood CS, Hartshorn MA, Tyndall JD, Hanson GR, Stokes KC, Leopold M, Multhaup G, Goldstein LE Scarpa RC, Saunders AJ, Lim J, Moir RD, Glabe C, Bowden EF, Masters CL, Fairlie DP, Tanzi RE, Bush AI (1999b) Cu(II) potentiation of Alzheimer $\mathrm{A} \beta$ neurotoxicity. Correlation with cell-free hydrogen peroxide production and metal reduction. J Biol Chem 274:37111-37116.

Ida N, Hartmann T, Pantel J, Schroder J, Zerfass R, Forstl H, Sandbrink R, Masters CL, Beyreuther K (1996) Analysis of heterogeneous A4 peptides in human cerebrospinal fluid and blood by a newly developed sensitive Western blot assay. J Biol Chem 271:22908-22914.

Iwatsubo T, Odaka A, Suzuki N, Mizusawa H, Nukina N, Ihara Y (1994) Visualization of $A \beta 42(43)$ and $A \beta 40$ in senile plaques with end-specific A $\beta$ monoclonals: evidence that an initially deposited species is A $\beta 42(43)$. Neuron 13:45-53.

Kay CJ (1997) Mechanochemical mechanism for peptidyl free radical generation by amyloid fibrils. FEBS Lett 403:230-235.

Kontush A, Berndt C, Weber W, Akopyan V, Arlt S, Schippling S, 
Beisiegel U (2001) Amyloid- $\beta$ is an antioxidant for lipoproteins in cerebrospinal fluid and plasma. Free Radic Biol Med 30:119-128.

LeVine 3rd H (1995) Soluble multimeric Alzheimer $\beta(1-40)$ preamyloid complexes in dilute solution. Neurobiol Aging 16:755-764.

LeVine 3rd H (1999) Quantification of $\beta$-sheet amyloid fibril structures with thioflavin T. Methods Enzymol 309:274-284.

Lorenzo A, Yankner BA (1994) $\beta$-amyloid neurotoxicity requires fibril formation and is inhibited by Congo red. Proc Natl Acad Sci USA 91:12243-12247.

Lovell MA, Xie C, Markesbery WR (1998a) Decreased glutathione transferase activity in brain and ventricular fluid in Alzheimer's disease. Neurology 51:1562-1566.

Lovell MA, Robertson JD, Teesdale WJ, Campbell JL, Markesbery WR (1998b) Copper, iron and zinc in Alzheimer's disease senile plaques. J Neurol Sci 158:47-52.

Markesbery WR, Lovell MA (1998) Four-hydroxynonenal, a product of lipid peroxidation, is increased in the brain in Alzheimer's disease. Neurobiol Aging 19:33-36.

Masters CL, Simms G, Weinman NA, Multhaup G, McDonald BL, Beyreuther K (1985) Amyloid plaque core protein in Alzheimer disease and Down syndrome. Proc Natl Acad Sci USA 82:4245-4249.

Mattson MP, Tomaselli KJ, Rydel RE (1993) Calcium-destabilizing and neurodegenerative effects of aggregated $\beta$-amyloid peptide are attenuated by basic FGF. Brain Res 621:35-49.

Michikawa M, Yanagisawa K (1998) Apolipoprotein E4 induces neuronal cell death under conditions of suppressed de novo cholesterol synthesis. J Neurosci Res 54:58-67.

Michikawa M, Gong JS, Fan QW, Sawamura N, Yanagisawa K (2001) A novel action of Alzheimer's $\beta$-protein $(\mathrm{A} \beta)$ : oligomeric $\mathrm{A} \beta$ promotes lipid release. J Neurosci 21:7226-7235.

Misonou H, Morishima-Kawashima M, Ihara Y (2000) Oxidative stress induces intracellular accumulation of amyloid $\beta$-protein $(\mathrm{A} \beta)$ in human neuroblastoma cells. Biochemistry 39:6951-6959.

Monji A, Utsumi H, Yoshida I, Hashioka S, Tashiro K, Tashiro N (2001a) The relationship between $A \beta$-associated free radical generation and $\mathrm{A} \beta$ fibril formation revealed by negative stain electron microscopy and thioflavin-T fluorometric assay. Neurosci Lett 304:65-68.

Monji A, Utsumi H, Ueda T, Imoto T, Yoshida I, Hashioka S, Tashiro K, Tashiro N (2001b) The relationship between the aggregational state of the amyloid- $\beta$ peptides and free radical generation by the peptides. J Neurochem 77:1425-1432.

Naiki H, Hasegawa K, Yamaguchi I, Nakamura H, Gejyo F, Nakakuki K (1998) Apolipoprotein $\mathrm{E}$ and antioxidants have different mechanisms of inhibiting Alzheimer's $\beta$-amyloid fibril formation in vitro. Biochemistry 37:17882-17889.

Nunomura A, Perry G, Pappolla MA, Friedland RP, Hirai K, Chiba S, Smith MA (2000) Neuronal oxidative stress precedes amyloid- $\beta$ deposition in Down syndrome. J Neuropathol Exp Neurol 59:1011-1017.

Nunomura A, Perry G, Aliev G, Hirai K, Takeda A, Balraj EK, Jones PK, Ghanbari H, Wataya T, Shimohama S, Chiba S, Atwood CS, Petersen RB, Smith MA (2001) Oxidative damage is the earliest event in Alzheimer disease. J Neuropathol Exp Neurol 60:759-767.

Pike CJ, Burdick D, Walencewicz AJ, Glabe CG, Cotman CW (1993)
Neurodegeneration induced by $\beta$-amyloid peptides in vitro: the role of peptide assembly state. J Neurosci 13:1676-1687.

Podlisny MB, Ostaszewski BL, Squazzo SL, Koo EH, Rydell RE, Teplow DB, Selkoe DJ (1995) Aggregation of secreted amyloid $\beta$-protein into sodium dodecyl sulfate-stable oligomers in cell culture. J Biol Chem 270:9564-9570.

Podlisny MB, Walsh DM, Amarante P, Ostaszewski BL, Stimson ER, Maggio JE, Teplow DB, Selkoe DJ (1998) Oligomerization of endogenous and synthetic amyloid $\beta$-protein at nanomolar levels in cell culture and stabilization of monomer by Congo red. Biochemistry 37:3602-3611.

Pratico D, Uryu K, Leight S, Trojanoswki JQ, Lee VM (2001) Increased lipid peroxidation precedes amyloid plaque formation in an animal model of Alzheimer amyloidosis. J Neurosci 21:4183-4187.

Roher AE, Lowenson JD, Clarke S, Woods AS, Cotter RJ, Gowing E, Ball MJ (1993) $\beta$-Amyloid-(1-42) is a major component of cerebrovascular amyloid deposits: implications for the pathology of Alzheimer disease. Proc Natl Acad Sci USA 90:10836-10840.

Roher AE, Chaney MO, Kuo YM, Webster SD, Stine WB, Haverkamp LJ, Woods AS, Cotter RJ, Tuohy JM, Krafft GA, Bonnell BS, Emmerling MR (1996) Morphology and toxicity of $A \beta-(1-42)$ dimer derived from neuritic and vascular amyloid deposits of Alzheimer's disease. J Biol Chem 271:20631-20635.

Sayre LM, Perry G, Harris PL, Liu Y, Schubert KA, Smith MA (2000) In situ oxidative catalysis by neurofibrillary tangles and senile plaques in Alzheimer's disease: a central role for bound transition metals. J Neurochem 74:270-279.

Schubert D, Chevion M (1995) The role of iron in $\beta$-amyloid toxicity. Biochem Biophys Res Commun 216:702-707.

Selkoe DJ (1994) Alzheimer's disease: a central role for amyloid. J Neuropathol Exp Neurol 53:438-447.

Smith MA, Harris PL, Sayre LM, Perry G (1997) Iron accumulation in Alzheimer disease is a source of redox-generated free radicals. Proc Natl Acad Sci USA 94:9866-9868.

Vigo-Pelfrey C, Lee D, Keim P, Lieberburg I, Schenk DB (1993) Characterization of $\beta$-amyloid peptide from human cerebrospinal fluid. J Neurochem 61:1965-1968.

Wang XF, Cynader MS (2001) Pyruvate released by astrocytes protects neurons from copper-catalyzed cysteine neurotoxicity. J Neurosci 21:3322-3331.

White AR, Multhaup G, Maher F, Bellingham S, Camakaris J, Zheng H, Bush AI, Beyreuther K, Masters CL, Cappai R (1999) The Alzheimer's disease amyloid precursor protein modulates copper-induced toxicity and oxidative stress in primary neuronal cultures. J Neurosci 19:9170-9179.

Yankner BA, Duffy LK, Kirschner DA (1990) Neurotrophic and neurotoxic effects of amyloid $\beta$ protein: reversal by tachykinin neuropeptides. Science 250:279-282.

Yoshiike Y, Tanemura K, Murayama O, Akagi T, Murayama M, Sato S, Sun X, Tanaka N, Takashima A (2001) New insights on how metals disrupt amyloid $\beta$-aggregation and their effects on amyloid- $\beta$ cytotoxicity. J Biol Chem 276:32293-32299. 